Digital Press Social Sciences and Humanities

The Use of Cooperative Learning Type Jigsaw in Improving Critical Thinking Skills of Student in Course Media Learning of PLS

Zahratul Azizah and Lili Dasa Putri

Proceeding of The Non-Formal Education International Conference 2020

Alim Harun Pamungkas, Jamaris, Solfema (eds) 


\title{
The Use of Cooperative Learning Type Jigsaw in Improving Critical Thinking Skills of Student in Course Media Learning of PLS
}

\author{
Zahratul Azizah*, Lili Dasa Putri \\ Department of Non-Formal Education Universitas Negeri Padang, Padang, Indonesia \\ *e-mail: zahratulazizah@fip.unp.ac.id
}

\begin{abstract}
The ability to think critically is one of the abilities that exist in the cognitive aspects which includes the ability to remember, understand, apply, analyze, synthesize, and assess. This ability starts from the simple thing to remember to solve the problem that requires a person to be able to connect and combine several ideas and ideas from what has been learned. In learning activities, there are still many students who have low critical thinking skills. This is evident in every lecture activity, students are more dominantly focused on presenting the reading sources obtained either through books or through other electronic media without being able to develop and explain logically or critically towards the reading sources. This study aims to describe the use of cooperative learning type jigsaw in improving students critical thinking skills in course Media Learning of PLS. The population of this research is students of PLS Department who take the course of PLS Learning Media and learning, and the sampling technique that will be carried out is accidental or convenience sampling. This research was designed using classroom action research methods which were carried out in 2 cycles, where each cycle contained stages: 1) planning; 2) implementation; 3) observation and interpretation; and 4) analysis and reflection.
\end{abstract}

\section{Keywords}

cooperative learning type jigsaw, critical thinking skills, learning

\section{Introduction}

One of the abilities should be owned and developed of students in lecture is the ability to think critically. This becomes a life skill for a person in dealing with various problems that exist in his life in the sense that a person is able to use his or her thought process to analyze an argument, then provide an interpretation based on correct and rational opinions, then analyze the assumptions and bias of the argument. as well as logical. The ability to think critically, of course, cannot be obtained just like that without a process in education, and not everyone can easily get it because to obtain this ability one must go through various stages in thinking.

Students as agents of change are expected to be able to provide meaningful changes in society. In this situation, students need to be equipped with skills in thinking in an effort to deal with the problems they have in their lives. The ability to think critically is one of the abilities that exist in the cognitive aspect. Bloom (1956) said that all efforts related to brain activity are in the cognitive domain, which relates to the ability to think, from simple to complex ones such as memorizing, understanding, applying, analyzing, synthesizing, and even evaluating.

Activities in lectures often do not prioritize the improvement of students' critical thinking skills, sometimes they are forgotten and more concerned with how to achieve learning goals without going through a critical thinking process. There are many students who are not able to develop their thinking skills in analyzing a problem they are facing, for example in a lesson, a new theme is given which is a development of an existing theme, many students are overwhelmed in attending lectures this is just a different theme, not to mention different problems. or a more complicated case. This is because students are not trained to be able to think critically, starting from analyzing, interpreting a problem, and even evaluating. 
One of the courses in the PLS FIP UNP Department is Media Learning of PLS which has a weight of 3 credits, held every odd semester. Based on the author's observations, it was found that students difficult to put forward ideas and opinions related to the learning topic in the course. When learning begins, most of them only accommodate the information provided by the lecturer, accepting without any criticism of the material provided. There are many students who are more dominant in explaining the reading sources they get either through books or through other electronic media without being able to develop and explain rationally, analyze, or critically of the reading sources. The habit of reading sources obtained by students makes students think, difficult to put forward their arguments or reasoning scientifically, of course, this is very unfortunate for the quality of these students.

The author assumes that in learning activities in these subjects, educators have not been able to create learning methods and strategies that can lead students to be able to think critically. Lecturers in providing learning to students on average still use conventional patterns, where learning activities are carried out by discussion, question, and answer. Students seem to play a more role as recipients of information only and lecturers are ready to provide it (Marzuki, 2010). Learning activities in this way have not been able to bring up students' critical thinking skills, even making students untrained to think critically, even though critical thinking can be interpreted as a process and the ability used to understand the concept, apply, synthesize and evaluate the information obtained or the information produced (Zubaidah, 2010).

In this research, researchers as educators in higher education want to try to do a classroom action research, using the jigsaw type of cooperative learning. In this learning, students can improve their critical thinking skills, especially students of the PLS FIP UNP Department who take Media Learning of PLS. Cooperative learning type jigsaw is a type of learning that focuses more on discussions conducted by expert groups and groups of origin (Hertiavi, 2010). During the discussion, there will be a process of cooperation between members in the group, each of them teaches each other, sharpens their skills in critical thinking. So the use of jigsaw type cooperative learning can improve students' critical thinking abilities in developing lecture material that students follow.

\section{Methods}

The subject of this study was students of the Department of Non-formal Education who were in the third semester of the 2019/2020 academic year. This research was conducted in the PLS FIP UNP Department, which is located on the Air Tawar Barat campus, North Padang District. This research is focused on the use of jigsaw cooperative learning in improving students thinking skills in the course of Media Learning of PLS. The research was conducted using classroom action research procedures carried out by lecturers as educators. It was designed using classroom action research methods which were carried out in 2 cycles.

This classroom action research is carried out with a cycle strategy that departs from problem identification, action planning, action implementation, action observation, and reflection. A sequential series of activities from action planning to reflection is called a research cycle. Each cycle consists of four stages, namely: (a) Planning the action: starting from the process of identifying the problem to be studied, including the results of pre-research. Then plan actions to be taken, including arranging the necessary learning tools and others; (b) Implementation of the action; implementation of learning in the classroom using the cooperative learning type jigsaw; (c) Observation and interpretation; observing the implementation process of learning activities using cooperative learning type jigsaw and; (d) Analysis and reflection: evaluating the results of data analysis about the results of an action taken in order to achieve research success through the use of the jigsaw type cooperative learning. This research was concluded in the second cycle. From this research, it is hoped that it will not only improve students' critical thinking skills but also improve their learning outcomes.

\section{Discussion}

\subsection{Critical Thinking Skills}

Critical thinking is a cognitive activity that is related to the use of one's reasoning starting from paying attention to an object, then categorizing it, selecting and making costs to taking action to decide. Wijaya 
(2010, p. 72) said that critical thinking was an activity to analyze ideas or ideas in a more specific direction, to distinguish them sharply, to select, study and develop them in a more perfect direction. Analytical activities in a complex matter for someone who does not have the ability at all, because this requires accuracy, sharpness in studying an idea or idea. Critical thinking is an active, persistent, and careful consideration of a belief or any form of knowledge that is received from various angles of reasons that support and conclude Surya (2011, p. 131).

The ability to think critically that is owned by a person will make it the right direction in thinking, working, and can help determine the relationship between something and others. The ability to think critically is an individual skill in using his or her thinking process to analyze arguments and provide interpretations based on correct and rational perceptions, analysis of assumptions, and bias from arguments and logical interpretations (Yamin, 2010). Therefore, this ability is needed in finding solutions to problems that are gathered from various information to the conclusion of an activity. These activities include the process of analyzing, explaining, developing or selecting ideas, categorizing, comparing and prioritizing, and making positive choices. Activities in the analysis process become one of the critical thinking skills because it starts by describing a structure into clear components. Describe something global and general then identify, describe, and relate something in a detailed and clear manner.

\subsection{Cooperative Learning Type Jigsaw}

Learning is an activity that seeks to teach students in an integrated manner by taking into account the learning environment, student characteristics, characteristics of the field of study, and various learning strategies (Uno, 2011). Cooperative learning is developed from thinking, democratic values, active learning, cooperative behavior, and respecting diversity in a multicultural society. Cooperative learning is a learning strategy that emphasizes collective attitudes or behaviors in working or helping among others in an orderly collaborative structure in groups of two or more people (Tampubolon, 2014).

Jigsaw type learning is included in cooperative learning. This learning is based on group activities with the diversity of students. Between students, there is a process of interdependence, mutual learning, and learning from each other, so that success in this learning is measured by the success of groups, not individuals.

Amri and Ahmadi (2010, p. 94) argue that the type of jigsaw cooperative learning is cooperative learning which consists of overcoming several members in one group who are responsible for mastering part of the learning material and are able to teach the material to other members of the group. In this type of jigsaw learning, students in large groups totaling approximately 30 people are divided into small groups consisting of 4-6 people heterogeneously and here there is a mutual learning process and they are responsible for the completeness of the part of the subject matter being studied and conveyed to members in other groups.

\subsection{The Steps in Implementing The Jigsaw Type Cooperative Learning}

The jigsaw cooperative learning model was developed by Elliot Aronson of the University of Texas USA. Implementation in the type of jigsaw learning is carried out as follows: briefing, teaching material information, create heterogeneous groups, provide teaching materials consisting of several parts according to the number of students in the group, each group member is tasked with discussing certain parts, each group of teaching materials is the same, create a group of experts according to the same part of the teaching material so there are cooperation and discussion, returning to the original group, conducting tutorials in the homegroup by members of the expert group, concluding and evaluating and reflecting.

Rusman (2014, p. 218) provides the following steps in the type of jigsaw cooperative learning: (1) Students are grouped with \pm 4 members; (2) Each person in the team is given different materials and assignments; (3) Members of different teams with the same assignment form a new group (expert group); (4) After the expert group has discussed, each member returns to the original group and explains to the group members about the sub-chapter they mastered; (5) Each expert team presents the results of the discussion; (6) Discussion and (7) Closing.

In general, the steps in implementing this learning strategy are that the class is divided into several groups where each group of students consists of 4-6 heterogeneous people and is given teaching materials and learning tasks that must be done. Each group is taken one member to form a new group or expert group with a discussion of the same task. In this group, a discussion is held between the expert group. The expert group members then return to the original group to teach their group members, 
wherein this group, discussion between group members is held. During the learning process as a group, the lecturer acts as a facilitator and motivator, every week or two the lecturer carries out an evaluation individually or in groups to find out the progress of student learning. In this group discussion process, where students teach each other, there is a process of collaboration, a communication process occurs which will lead to the critical thinking ability of each student in conveying their arguments in the discussion.

The steps in the implementation of jigsaw type learning in the PLS media and teaching materials course are carried out as follows: the lecturer delivers information related to the material and submaterial in media learning. Lecturers form student groups consisting of 4-6 people. If in one group there are 30 students, then there are 5 groups with 6 members each. Each group was given different materials and materials. Each member of the group is in charge of studying the material that has been given. Then in each group, a representative of one person is appointed who will later separate themselves because they will become an expert group or expert group. After completing the discussion as a team of experts, members return to the original group and convey information to the original group, in turn, the lecturer evaluates the student's inaccurate answers or responses, and the lecturer conducts tests orally or in writing and finally closes or conclusions from learning activities from the eye lecture media and PLS study materials.

\section{Conclusions}

Students' critical thinking skills can be developed by using the jigsaw type cooperative learning. This learning is carried out for students who are divided into small groups consisting of 4-5 people by paying attention to heterogeneity, working together positively and each member is responsible for studying certain problems from the material provided and conveying the material to other group members.

\section{References}

Amri, S., \& Ahmadi, K. I. (2010). Konstruksi Pengembangan Prmbelajaran. Jakarta: PT. Prestasi Pustakaraya.

Bloom, B. S. (1956). Taxonomy of Educational Objectives. Handbook I: The Cognitive Domain. New York: David McKay Co Inc.

Hertiavi. (2010). Penarapan Model Pembelajaran Kooperatif Tipe Jigsaw untuk Peningkatan Kemampuan Pemecahan Masalah Siswa SMP. Jurnal Pendidikan Fisika Indonesia, 6(1). Retrieved from https://journal.unnes.ac.id/nju/index.php/JPFI/article/view/1104)

Marzuki, S. (2010). Pendidikan Nonformal. Bandung: Remaja Rosdakarya.

Rusman. (2014). Model-model Pembelajaran. Mengembangkan Profesionalisme Guru. Jakarta: PT. Raja Grafindo Persada.

Surya, H. (2011). Strategi Jitu Mencapai Kesuksesan Belajar. Jakarta: Gramedia.

Tampubolon, S. (2014). Penelitian Tindakan Kelas sebagai Pengembangan Profesi Pendidik dan Keilmuan. Jakarta: Erlangga.

Uno, H. (2011). Model Pembelajaran Menciptakan Proses Belajar Mengajar yang Kreatif dan Efektif. Jakarta: Bumi aksara.

Wijaya, C. (2010). Pendidikan Remidial: Sarana Pengembangan Mutu Sumber Daya Manusia. Bandung: Remaja Rosdakarya.

Yamin, M. (2010). Kiat Membelajarkan Siswa. Jakarta: Gaung Persada Press. 
Zubaidah, S. (2010). Berfikir Kritis: Kemampuan Berfikir Tingkat yang dapat dikembangkan melalui Pembelajaran Sains. Seminar Nasional Sains 2010 Dengan Tema “Optimalisasi Sains Untuk Memberdayakan Manusia." Surabaya: Pascasarjana Universitas Negeri Surabaya. 